\title{
Bacillus Calmette-Guérin induces rapid gene expression changes in human bladder cancer cell lines that may modulate its survival
}

\author{
JUWITA N. RAHMAT ${ }^{1}$, KESAVAN ESUVARANATHAN $^{1,2}$ and RATHA MAHENDRAN ${ }^{1}$ \\ ${ }^{1}$ Department of Surgery, Yong Loo Lin, School of Medicine, National University of Singapore; \\ ${ }^{2}$ National University Hospital, National University Health System, Singapore 119228, Republic of Singapore
}

Received June 14, 2016; Accepted March 9, 2018

DOI: $10.3892 / \mathrm{ol} .2018 .8462$

\begin{abstract}
Bacillus Calmette-Guérin (BCG) immunotherapy is the standard therapy for non-muscle invasive bladder cancer. The aim of the present study was to identify genes that are induced in response to BCG immunotherapy, as these may be potential biomarkers for the response to clinical therapy. To model clinical therapy, human bladder cancer cell lines were incubated with BCG (live or lyophilized BCG Connaught) for $2 \mathrm{~h}$. RNA was extracted and evaluated by Representational Differential Analysis (RDA) and oligo arrays. Gene expression was confirmed by reverse transcription polymerase chain reaction on fresh cell lines with differential abilities to internalize BCG. The effect of 2 major BCG soluble proteins, antigen 85B (Ag85B) and Mycobacterium protein tyrosine phosphatase A (MptpA) and BCG Tice ${ }^{\circledR}$ on gene expression was also determined. $G A P D H$ and $\beta$-actin, which are normally used as control genes, were upregulated by BCG. Therefore, the ribosomal RNA gene ribosomal protein S27a was used to normalize gene expression. The genes likely to be induced by BCG internalization and soluble factors were: GSTT2, MGST2, CCL20, TNF $\alpha, C C N E 1$ and IL1ORB. Those induced by BCG membrane interactions and/or soluble factors were: MGST1, CXCL6, IL12A, CSF 2, IL1 $\beta$ and TOLLIP. MptpA decreased GSTT2 expression, and Ag85B increased TNF $\alpha$ expression. The two BCG strains significantly increased GSTT2, TNF $\alpha$ and TOLLIP levels in MGH cells. However, in J82 cells there was a BCG strain-dependent difference in $T N F \alpha$ expression. An important outcome of the present study was the determination that neither GAPDH nor $\beta$-actin were suitable control genes for the analysis of BCG-induced gene expression. BCG Connaught and Tice ${ }^{\circledR}$ induced similar expression
\end{abstract}

Correspondence to: Dr Ratha Mahendran, Department of Surgery, Yong Loo Lin, School of Medicine, National University of Singapore, Level 8 NUHS Tower Block, 1E Kent Ridge Road, Singapore 119228, Republic of Singapore

E-mail: surrm@nus.edu.sg

Key words: Bacillus Calmette-Guérin, gene expression, bladder cancer, cell lines levels of genes in bladder cancer cell lines. BCG soluble proteins modulated gene expression and therefore may affect therapeutic outcomes. The genes identified may be novel biomarkers of the response to BCG therapy.

\section{Introduction}

The standard treatment for non-muscle invasive bladder cancer is transurethral resection of the tumor (TUR) followed by intravesical instillation of lyophilized Bacillus Calmette-Guérin (BCG) (1). BCG induces a non-specific immune response that is believed to remove remnant tumor cells (1) and direct $\mathrm{BCG}$ interaction with cancer cells may have a role in this response (2).

BCG is internalized by bladder cancer cells via the $\alpha 5 \beta 1$ integrin complex (3), and cross-linking of this receptor by BCG induces gene expression (4). The internalization process occurs via micropinocytosis (5), as opposed to phagocytosis. BCG internalization is associated with decreased production of reactive oxygen species (ROS) and thiols (6) and increased cell death. BCG-induced cell death has been revealed to be associated with NO production (7), and is necrotic, involving the release of HMGB1, which exhibits paracrine effects on urothelial cells (8).

Lyophilized and live BCG induce differential ROS modulation in A549 lung epithelial cancer cells (9) and human bladder cancer cell lines (10), probably as lyophilized preparations contain extruded cellular components, secreted BCG proteins and whole bacteria. Similarly, intravesical instillation of live and inactivate BCG preparations in mice induced differential cytokine/chemokine gene expression (11).

The present study further elucidates the cellular changes induced by BCG interaction with cancer cells in the clinical time-frame of $2 \mathrm{~h}$. In this time frame, RNA expression changes are easily detected compared with changes in protein levels. A stimulated cell may trigger novel mRNA synthesis within a few min, but protein production requires a longer time period. The genes induced within $2 \mathrm{~h}$ will generate proteins that will in turn lead to the expression of other genes. Therefore, studies evaluating expression at time points beyond $2 \mathrm{~h}$ are examining primary, secondary or even tertiary responses to the original stimulus. Genes whose expression is triggered immediately following interaction with BCG may be specific markers of the response to BCG immunotherapy. 
Several BCG strains are used to treat bladder cancer. Genetic analyses have indicated that these strains have genetic differences $(12,13)$ that affect their anti-proliferative effects on human bladder cancer cell lines. Therefore, the ability of the two most commonly used BCG strains, namely BCG Connaught and Tice, to modulate gene expression was compared. It was hypothesized that genes induced by these similar strains are likely to be important for the response of cells to BCG.

To evaluate gene expression changes, human bladder cancer cell lines with known differential ability to internalize BCG (14) were exposed to BCG for $2 \mathrm{~h}$ in the present study. This allowed differentiation between responses induced by $\mathrm{BCG}$ internalization, and identification of those responses likely to be induced by membrane interactions. The effect of major BCG soluble proteins Ag85B and Mycobacterium protein tyrosine phosphatase A (MptpA) on gene expression was also determined. RNA was extracted from these cells, subjected to the representational differential analysis (RDA) (15) and used to probe oligo arrays to identify differentially expressed genes.

\section{Materials and methods}

Preparation of bacteria. Lyophilized BCG strains [(Connaught; Sanofi S.A., Paris, France) and Tice (Merck Sharp \& Dohme, Whitehouse Station, NJ, USA)] were prepared as previously described (10). BCG was maintained in 7H9 Middlebrook media (Difco ${ }^{\mathrm{TM}}$; BD Biosciences, Franklin, NJ, USA) supplemented with $10 \%$ ADC supplement $(0.85 \% \mathrm{NaCl}, 5 \%$ bovine serum albumin fraction V, $2 \%$ dextrose and $0.003 \%$ catalase; Sigma-Aldrich; Merck KGaA, Darmstadt, Germany), 0.05\% Tween- 80 and $0.2 \%$ glycerol. Live Connaught BCG was grown on 7H10 Middlebrook agar supplemented with $10 \%$ ADC supplement, $0.05 \%$ Tween- 80 and $0.5 \%$ glycerol, and single colonies were selected for growth. BCG cultures were harvested at 0.7 to $0.8 \mathrm{OD}_{600 \mathrm{~nm}}$ at the exponential phase. The formula $\mathrm{OD}_{600 \mathrm{~nm}} 0.1=2.6 \times 10^{6}$ colony forming units (c.f.u.) $/ \mathrm{ml}$ was established by plating serial dilutions of BCG culture on 7H10 Middlebrook agar with supplements.

Mammalian cell culture. Human transitional cell carcinoma cell lines MGH, RT4 and J82 (American Type Culture Collection, Manassas, VA, USA) were cultured in RPMI (Biowest, Nuaillé, France) supplemented with $10 \%$ heat inactivated fetal bovine serum (Biowest), $2 \mathrm{mM} \mathrm{L}$-glutamine, $50 \mathrm{U} / \mathrm{ml}$ penicillin $\mathrm{G}$ and $50 \mu \mathrm{g} / \mathrm{ml}$ streptomycin at $37^{\circ} \mathrm{C}$ in $5 \%$ $\mathrm{CO}_{2}$ and routinely passaged when $85-90 \%$ confluent. The cells $\left(2 \times 10^{6}\right)$ plated overnight were incubated with $2 \times 10^{7} \mathrm{cfu}$ live or lyophilized $\mathrm{BCG}$ at $37^{\circ} \mathrm{C}$ for $2 \mathrm{~h}$. A Transwell device blocked direct contact between BCG and the cells. Sodium orthovandate $(100 \mu \mathrm{M})$ inhibited tyrosine phosphatase activity. Purified MptpA at $0.5 \mu \mathrm{g} / \mathrm{ml}$ and $5 \mu \mathrm{g} / \mathrm{ml}$, prepared as described previously (10), was added to the cells at $37^{\circ} \mathrm{C}$ for $2 \mathrm{~h}$, and RNA was isolated. Ag85B (Sigma-Aldrich; Merck KGaA) at a concentration of $1 \mu \mathrm{g} / \mathrm{ml}$ was added to the cells. For verification of gene expression, the experiments were performed three times in duplicate.

RNA extraction and RDA. MGH $\left(6 \times 10^{5}\right)$ cells were plated in a $10 \mathrm{~mm}$ cell culture dish overnight prior to treatment with
$6 \times 10^{7} \mathrm{cfu}$ of lyophilized $\mathrm{BCG}$ at $37^{\circ} \mathrm{C}$ for $2 \mathrm{~h}$. Total RNA was extracted using TRIzol ${ }^{\circledR}$ (Invitrogen; Thermo Fisher Scientific, Inc., Waltham, MA, USA). Then, poly $\mathrm{A}^{+} \mathrm{RNA}$ was isolated using the Oligote ${ }^{\circledR}$ mRNA midi kit (Qiagen, Inc., Valencia, CA, USA) and converted to cDNAs with Riboclone ${ }^{\circledR}$ cDNA Synthesis system (Promega Corporation, Madison, WI, USA), according to the manufacturer's protocols. The RDA was performed as described by Pastorian et al (15). The samples with and without BCG treatment were subjected to repeated rounds of subtractive hybridization at 1:10, 1:100 and 1:5,000 tester to driver ratios. Only products that were upregulated in the tester population were amplifiable by polymerase chain reaction (PCR). The PCR amplified products were ligated into pGEM $^{\circledR}$ T Easy Vector (Promega Corporation), transformed into DH5 $\alpha$ cells and positive clones were selected on LB agar plates with $100 \mu \mathrm{g} / \mathrm{ml}$ ampicillin. Plasmid DNA was isolated (Promega Corporation) and sequenced with-21M13 forward primers (5'-GTAAAACGACGGCCAGT-3') using the BigDye version 3.0 system (Applied Biosystems; Thermo Fisher Scientific, Inc.). The sequencing results were identified using the BLAST algorithm (https://blast.ncbi.nlm.nih. gov/Blast.cgi).

Expression array analysis. PolyA ${ }^{+}$mRNA samples were converted to Biotin-16-UTP (Roche Diagnostics, Indianapolis, IN, USA) labeled cRNA using the TrueLabelling-AMP ${ }^{\mathrm{TM}}$ Linear RNA Amplification kit (SABiosciences, Frederick, MD, USA). The labeled cRNA was purified from interfering free Biotin-16-UTP using the Array Grade cRNA Cleanup kit (SABiosciences). The yield of cRNA samples were quantified using the formula as follows: Concentration $(\mu \mathrm{g} / \mathrm{ml})=\mathrm{OD} 260 \times 40 \times$ dilution factor (dilution factor, 350). The Inflammatory Cytokines and Receptors and Toxicology and Drug Resistance microarray (OHS401, SABiosciences) was assayed as previously described (16). Chemiluminescence detection was performed using the SABiosciences Chemiluminescent Detection Kit and X-ray films. Blot intensity analysis was performed using SABiosciences GEArray Expression Analysis Suite online software (http://saweb2. sabiosciences.com/support_software.php).

Reverse transcription (RT-PCR. A total of $\sim 5 \mu \mathrm{g}$ of RNA was pre-treated with $1 \mathrm{U}$ DNAse in $1 \mathrm{X}$ DNAse buffer $(20 \mathrm{mM}$ Tris. $\mathrm{Cl} \mathrm{pH} \mathrm{8.4,20} \mathrm{mM} \mathrm{MgCl}_{2}, 500 \mathrm{mM} \mathrm{KCl}$ ) and 40 U RNAsin for $15 \mathrm{~min}$ at room temperature, and digestion was terminated by the addition of EDTA (final concentration, $2.5 \mathrm{mM}$ ). Oligo dT $(0.5 \mu \mathrm{g})$ was added, and the mixture was incubated at $65^{\circ} \mathrm{C}$ for $10 \mathrm{~min}$, then chilled on ice for $5 \mathrm{~min}$ prior to the addition of the cDNA synthesis buffer (50 mM Tris pH $8.3,75 \mathrm{mM} \mathrm{KCl}$, $3 \mathrm{mM} \mathrm{MgCl}$ ), $0.5 \mathrm{mM}$ dNTPs (Promega Corporation), $8 \mathrm{U}$ RNAsin (Promega Corporation), 200 U SuperScript II enzyme (Invitrogen; Thermo Fisher Scientific, Inc.) and incubation at $42^{\circ} \mathrm{C}$ for $50 \mathrm{~min}$. The reaction was terminated by heating at $70^{\circ} \mathrm{C}$ for $15 \mathrm{~min}$, and then the samples were diluted with $180 \mu \mathrm{l}$ TE buffer (20 mM Tris pH 8.0, $1 \mathrm{mM}$ EDTA). PCR was performed on cDNAs $(5 \mu \mathrm{l})$ with $0.5 \mu \mathrm{M}$ gene-specific primers, $0.2 \mathrm{mM}$ dNTPs, $0.5 \mathrm{U}_{\text {DyNAzyme }}^{\mathrm{TM}}$ DNA polymerase (Finnzymes; Thermo Fisher Scientific, Inc.) in $10 \mathrm{mM}$ Tris $\mathrm{pH} 8.8,50 \mathrm{mM} \mathrm{KCl}, 1.5 \mathrm{mM} \mathrm{MgCl}_{2}$ and $0.1 \%$ Triton $^{\circledR}$ $\mathrm{X}-100$. The PCR products were separated on a $1.5 \%$ agarose 
Table I. Primers and conditions for polymerase chain reaction.

\begin{tabular}{|c|c|c|c|c|}
\hline Gene & Forward $\left(5^{\prime}-3^{\prime}\right)$ & Reverse $\left(5^{\prime}-3^{\prime}\right)$ & Temperature, ${ }^{\circ} \mathrm{C}$ & Size, bp \\
\hline TNF $\alpha$ & GTGTGGCCTGCACAGTGA & GGAGCAGAGGCTCAGCAA & 56 & 550 \\
\hline $\operatorname{IL} 1 \beta$ & ACATGCCCGTCTTCCTGG & GGGAAGCGGTTGCTCATC & 56 & 421 \\
\hline TOLLIP & GGACAGGCTTGTCTGCCA & CGCACGTTCTGAGACCAC & 56 & 317 \\
\hline CCL20 & GCCAATGAAGGCTGTGAC & ACAAGTCCAGTGAGGCAC & 54 & 262 \\
\hline CSF2 & CAGGAGCCGACCTGCCTA & TCAGGGTCAGTGTGGCCC & 58 & 388 \\
\hline IL10RB & CCTTAGAGGTCGAGGCAG & GTCCGTGCTCTGTGTAGC & 56 & 420 \\
\hline CXCL6 & CCAGTCTTCAGCGGAGCA & ССТСССТСАACAGCACAC & 54 & 384 \\
\hline IL12A & AATGGGAGTTGCCTGGCC & ACGGTTTGGAGGGACCTC & 56 & 364 \\
\hline CXCL5 & GGACCAGAGAGAGCTTGG & GTGTGTCCCACCAGGACT & 56 & 373 \\
\hline IL11RA & TCTGGCTGAGGCTGAGAC & TCCCTGCCTCACAGACAC & 56 & 370 \\
\hline IL15RA & AGCTTCCCAGGAGAGACC & TCCCAGGTCCCTGTCCAT & 56 & 279 \\
\hline SCYE1 & TGGAGAGAGGAAGTTGCC & GTCAGGGTTACTCTGGCA & 54 & 357 \\
\hline GSTA3 & ATGGACGGGGCAGAATGG & GGAGATAAGGCTGGAGTC & 54 & 497 \\
\hline GSTT2 & AGGCTCGTGCCCGTGTTC & GGCCTCTGGTGAGGGTG & 58 & 428 \\
\hline GSTM5 & CAGAAGATGGGAGGGAGG & GGGGGACTTTGATGGAGG & 56 & 207 \\
\hline MGST1 & GCAGAGCCCACCTGAATG & TCСТСТGCTCСССТССТА & 56 & 354 \\
\hline MGST2 & AGACCTGCCTGCCTTCCT & CCACCCAGCCATCCACAA & 56 & 392 \\
\hline HSPA6 & CAGTGGCATCCCTCCTGC & GCGGGCTTGAGTGCCACA & 58 & 499 \\
\hline NOS2A & CCTGGCAAGCCCAAGGTC & CACCCACTTGCCAGGCCT & 58 & 587 \\
\hline NAT2 & GTGACCATTGACGGCAGG & CGTGAGGGTAGAGAGGAT & 54 & 630 \\
\hline NAT5 & CCTTTACCTGCGACGACC & GGAGGAGACTGGAGCAAG & 56 & 830 \\
\hline$\beta$-ACTIN & AAATCGTGCGTGACATTAAGG & AGCACTGTGTTGGCGTACAG & 50 & 277 \\
\hline GAPDH & GGAAGGACTCATGACCAC & GGTCTCTCTCTTCСTCTT & 53 & 546 \\
\hline RPS27A & CTCGAGGTTGAACCCTCG & GCACTCTCGACGAAGGCG & 56 & 321 \\
\hline
\end{tabular}

TNF, tumor necrosis factor; IL, interleukin; TOLLIP, Toll interacting protein; CCL20, C-C motif chemokine ligand 20; CSF2, colony stimulating factor 2; CXCL, C-X-C motif chemokine ligand; IL11RA, Interleukin 11 receptor subunit $\alpha$; IL15RA, interleukin 15 receptor subunit $\alpha$; SCYE1, ARS-interacting multifunctional protein 1; GSTA3, glutathione S-transferase $\alpha 3$; GSTT2, glutathione S-transferase $\theta 2$; GSTM5, glutathione S-transferase $\mu 5$; MGST, microsomal glutathione S-transferase; HSPA6, heat shock protein family A (Hsp70) member 6; NOS2A, nitric oxide synthase 2; NAT2, N-acetyltransferase 2; NAT5, N(alpha)-acetyltransferase 20, NatB catalytic subunit; RPS27A, ribosomal protein S27a.

gel, and the relative density of the gene-specific PCR products and ribosomal protein S27a (RPS27A) was determined using the GeneTools densitometry software (version 3.0; Syngene Europe, Cambridge, UK). Gene expression data is presented as the mean \pm standard error. Table I lists the sequences of the PCR primers, annealing temperature and size of the PCR products. The thermocycling conditions comprise one initial denaturation step at $94^{\circ} \mathrm{C}$ for $5 \mathrm{~min}$ followed by repeated amplification cycles of $94^{\circ} \mathrm{C}$, primer annealing temperature and $72^{\circ} \mathrm{C}$ for $30 \mathrm{sec}$ each and one final extension step at $72^{\circ} \mathrm{C}$ for $5 \mathrm{~min}$. The appropriate number of PCR cycles for each primer set was determined by plotting the density of the PCR products at 30,35 and 40 cycles. For the majority of the genes, 30 and 35 cycles were suitable for differential expression analysis.

Statistical analysis. For analysis between two or more samples, one-way analysis of variance with post hoc Bonferroni test was used. Independent sample t-tests were used for comparisons between two samples. $\mathrm{P}<0.05$ was considered to indicate a statistically significant difference.

\section{Results}

GAPDH and $\beta$-actin are induced by BCG in bladder cancer cells. MGH cells, which readily internalize BCG, were exposed to BCG Connaught for $2 \mathrm{~h}$, and the RNA was extracted and subjected to several rounds of subtractive hybridization. The RNA was subsequently cloned and sequenced following the protocol developed by Pastorian et al (15). A total of 56 clones were isolated (from control and BCG treated samples) and sequenced. The sequences were identified by using the BLAST program on GenBank. The genes identified are listed in Table II. A total of 6 genes were chosen for validation by RT-PCR on fresh samples, but only 2 genes ( $\beta$-actin and $G A P D H$ ) were confirmed to be induced in $\mathrm{MGH}$ and RT4 cells exposed to lyophilized and live BCG (Fig. 1). The other genes identified: Glutathione-S-transferase $\kappa$; heat shock protein 70 protein 5; natural killer cell enhancing factor; and $\beta 1$ integrin, were not differentially modulated. As RT4 cells do not internalize BCG as well compared with MGH cells (10), the gene expression changes induced in RT4 cells may be due to membrane signaling or the uptake of BCG soluble factors. 

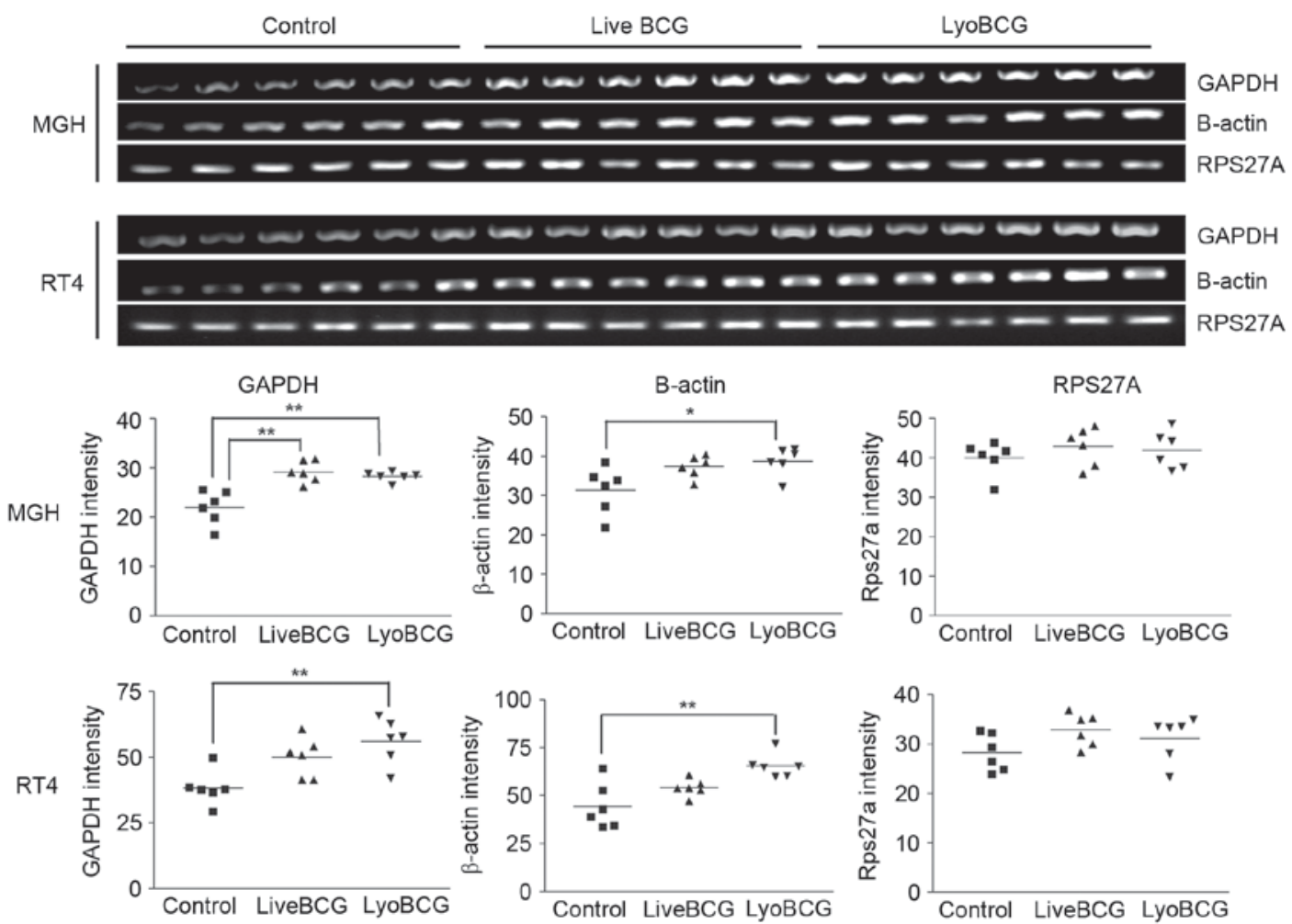

Figure 1. Reverse transcription polymerase chain reaction analysis of common housekeeping genes following exposure to BCG for $2 \mathrm{~h}$. All PCR was performed for 35 cycles. The live and lyophilized BCG significantly increased GAPDH transcript levels in MGH cells, while only lyophilized BCG increased GAPDH levels in the RT4 cell line. For $\beta$-actin, only lyophilized BCG treatment significantly increased transcript expression. No significant differences were observed in the expression of the RPS27A gene. The data presented is from 3 independent sets of experiments performed in duplicate. ${ }^{*} \mathrm{P}<0.05$ and ${ }^{* *} \mathrm{P}<0.005$ using one-way analysis of variance multiple comparisons with Bonferroni correction. Lyo, lyophilized; RPS27A, ribosomal protein S27a; BCG, Bacillus Calmette-Guérin.

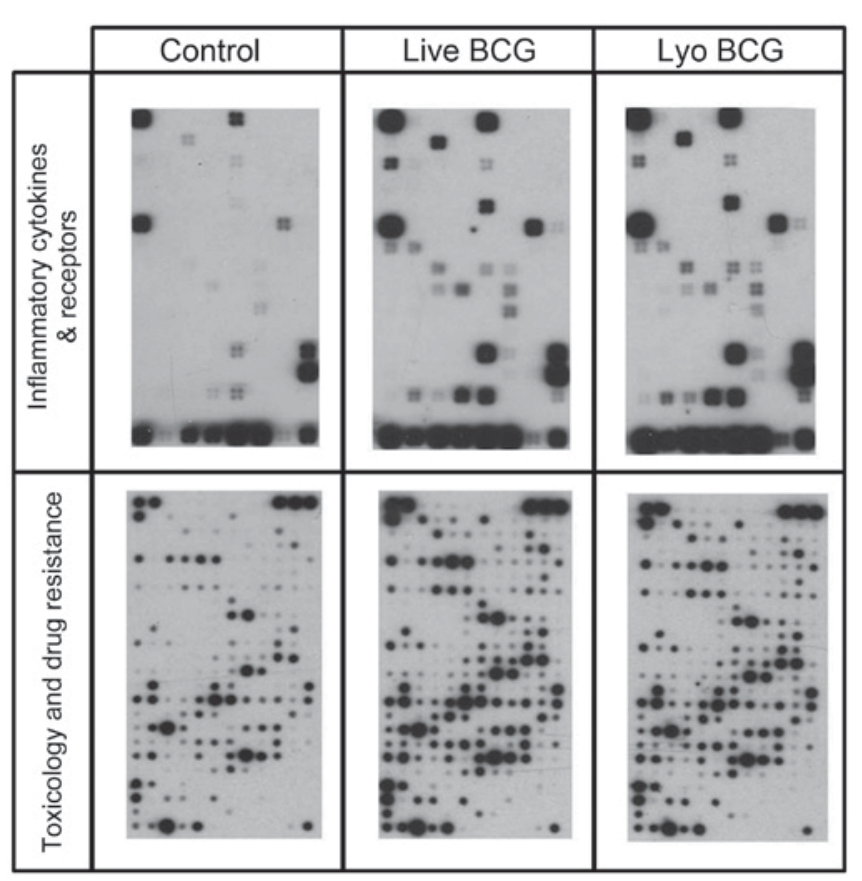

Figure 2. Inflammatory cytokines and receptors, and toxicology and drug resistance oligo arrays. MGH cells were treated with live or lyophilized BCG for $2 \mathrm{~h}$. Poly $\mathrm{A}^{+}$mRNA harvested from each sample was converted to biotin labeled cRNA, which were then used to probe the inflammatory cytokines and receptors, and toxicology and drug resistance oligo arrays. Live and lyophilized BCG were found to upregulate a similar number of genes with at least a 2 -fold difference in each array. BCG, Bacillus Calmette-Guérin. $\beta$-actin and GAPDH are normally used as controls for gene expression analysis, and normalization with these genes would lead to erroneous interpretation of gene expression changes. A ribosomal protein gene, RPS27A, was identified not to vary in response to BCG and was used as a control gene (Fig. 1). One limitation of the RDA strategy was that often the sequence identified had homology to a conserved domain of a family of associated genes, which meant it was difficult to identify the actual family member that was induced. Therefore, oligo arrays with detoxification genes and inflammatory cytokine genes were also analyzed.

Live and lyophilized BCG induced differential gene expression. Several genes were identified to be differentially expressed on the arrays following exposure of MGH cells to live or lyophilized BCG (Fig. 2). The Inflammatory Cytokines \& Receptors array contained oligonucleotides representing 61 genes, and the Toxicology \& Drug Resistance array contained 386 genes. A total of 17 genes on the Inflammatory Cytokines \& Receptors array and 59 genes on the Toxicology \& Drug Resistance array were differentially expressed by $>2$-fold (Tables III and IV). To re-confirm the array data, 20 genes with $>5$-fold difference in expression levels and 2 that were increased $\sim 2$-fold were chosen for RT-PCR analysis on fresh MGH and RT4 cells exposed to lyophilized and live BCG for $2 \mathrm{~h}$. A total of 10 genes $(C X C L 5$, IL11RA, IL15RA, SCYE1, HSPA6, NAT2, NAT5, GSTM5, GSTA3 and NOS2A) were not detectable during RT-PCR validation. The two cells lines differentially expressed certain 
Table II. Differentially expressed genes as determined by representational differential analysis.

\begin{tabular}{ll} 
Class of protein & Control Sample \\
\hline $\begin{array}{l}\text { Membrane proteins/ } \\
\text { adhesion molecules }\end{array}$ & $\bullet$ Chondroitin sulphate \\
proteoglycan 6 (NM_005445.2)
\end{tabular}

Detoxification, antioxidants and stress response

\author{
- Diaphorase NADH/NADPH \\ cytochrome b5 reductase (BC007659)
}

Intracellular motility/

Cell structure integrity

Enzymes and regulatory proteins

Transcription factors and nuclear proteins
- Kinesin (NM_004521.1)

- Dynein (NM_003746.1)

- Thymosin $\beta 4$ (NM_021109.1)

- Inhibitor of $\kappa$ light polypeptide gene enhancer (NM_003640.1)

- Cytoplasmic antiproteinase 38 kDa (S69272)

- Enolase 1 (NM_001428.21)

- Lactate dehydrogenase A (NM_005566.1)

- Spermine N1-Acetyltransferase (NM_002970.1)

- Transcription factor 2 (NM_000548.1)

- Nucleolin (NM_005381.1)

- DNA polymerase, Epsilon 3, p17

subunit (NM_017443.3)

- Histone acetyltransferase 1 (NM_003642.1)

Lyo BCG treated sample

- Integrin $\beta 1$ (NM_133376.1)

- CD81 antigen (NM_004356.2)

- Connexin 45 (NM_005497.1)

- Translocase of Inner mitochondrial) membrane 17 (NM_006335.1)

- ATP synthase $\mathrm{H}^{+}$transporting protein, alpha subunit (BT008024)

- Gluthathione-S-Transferase

subunit 13 (NM_015917.1)

- Heat Shock protein 70 (NM_005347.2)

- Natural Killer cell enhancing factor

(HUMNKEFA)

- Peroxiredoxin 1 (NM_002574.2)

- Clathrin assembly protein 50 (HSU36188)

- $\beta$-Actin (NM_001101.2)

- c-myc binding protein (HUMCMYCQ)

- Protein kinase cAMP dependent regulatory, type 1 $\alpha$ (NM_002734.2)

- 6-phosphofructo-2-kinase

(NM_004567.2)

- Glyceraldehyde-3-phosphate

dehydrogenase (NM_002046.2)

- Follistatin like protein

(NM_008047.2)

- Metallo- $\beta$-lactamase (D83198)

- Ribophorin (Y00281)

- Archain 1 (NM_001655.3)

NADH, nicotinamide adenine dinucleotide; NADPH, nicotinamide adenine dinucleotide phosphate; CD, cluster of differentiation; ATP, adenosine 5'triphosphate; cAMP, cyclic adenosine 5'-monophosphate.

genes in their basal state (Table V). Unstimulated MGH cells expressed significantly higher levels of TNF $\alpha, I L 12 A, C X C L 6$, CCL20, CSF2, IL1ORB, TOLLIP, GSTT2 and CCNE1 when compared with RT4 cells $(\mathrm{P}<0.05)$. MGST1 expression was higher in RT4 cells, compared with MGH cells. For MGH cells exposed to live or lyophilized $\mathrm{BCG}$, the expression of the following genes: CCL20, CXCL6, IL12A, MGST2, IL10RB and $C C N E 1$ were significantly reduced $(\mathrm{P}<0.005$ except CXCL6, P<0.05), compared with unstimulated MGH cells. While TNF $\alpha$ and TOLLIP expression levels were increased on exposure to live BCG (Table V), compared with unstimulated MGH cells $(\mathrm{P}<0.005$ and $\mathrm{P}<0.05$ respectively), only $\mathrm{TNF} \alpha$ was significantly increased following exposure to lyophilized BCG $(\mathrm{P}<0.005$ when compared with unstimulated $\mathrm{MGH}$ cells). MGST1 and GSTT2 were increased only in lyophilized BCG-treated MGH cells. In the RT4 cells, MGST1, CSF 2 and TOLLIP expression levels increased, while CXCL6 expression decreased following exposure to live or lyophilized BCG (Table V). However, ILI $\beta$ was significantly decreased following lyophilized BCG exposure $(\mathrm{P}<0.05)$ and IL12A expression was significantly decreased following live BCG exposure in RT4 cells $(\mathrm{P}<0.05)$, compared with unstimulated RT4 cells. Similar gene expression changes between MGH and RT4 cell lines probably indicated genes whose expression resulted from the interaction of BCG or BCG-soluble factors with cellular receptors, while genes increased in $\mathrm{MGH}$ and unchanged in RT4 are likely due to BCG internalization, as MGH cells readily internalize BCG, unlike RT4 cells.

GSTT2, TNF $\alpha$ and TOLLIP expression are modulated by $B C G$ soluble factors. The effects of BCG-soluble factors were examined on 3 genes: GSTT2 and TNF $\alpha$ (increased in MGH and not RT4 cells); and TOLLIP (increased in the two cell lines). A membrane insert was $\leq$ used to separate whole BCG from the cells to examine the effect of BCG soluble (secreted) factors. There was a significant decrease $(\mathrm{P}<0.005)$ in GSTT2 expression in live BCG-treated $(0.08 \pm 0.04)$ and lyophilized BCG-treated $(0.09 \pm 0.04)$ cells compared with the control 
Table III. Differentially expressed genes ${ }^{\mathrm{a}}$ on the Human Inflammatory Cytokines and Receptors oligo array.

\begin{tabular}{|c|c|c|}
\hline Ref Seq number & Symbol & Description \\
\hline NM_004591 & CCL2O & Chemokine (C-C motif) ligand 20 \\
\hline NM_005624 & CCL25 & Chemokine (C-C motif) ligand 25 \\
\hline NM_005194 & $C E B P B$ & CCAAT/enhancer binding protein $(\mathrm{C} / \mathrm{EBP}), \beta$ \\
\hline NM_002090 & CXCL3 & Chemokine (C-X-C motif) ligand 3 \\
\hline NM_002994 & CXCL5 & Chemokine (C-X-C motif) ligand 5 \\
\hline NM_002993 & CXCL6 & $\begin{array}{l}\text { Chemokine (C-X-C motif) ligand } 6 \\
\text { (granulocyte chemotactic protein } 2 \text { ) }\end{array}$ \\
\hline NM_000628 & ILIORB & Interleukin 10 receptor, $\beta$ \\
\hline NM_004512 & ILIIRA & Interleukin 11 receptor, $\alpha$ \\
\hline NM_000882 & IL12A & $\begin{array}{l}\text { Interleukin } 12 \mathrm{~A} \text { (natural killer cell stimulatory factor } 1 \text {, } \\
\text { cytotoxic lymphocyte maturation factor } 1, \mathrm{p} 35 \text { ) }\end{array}$ \\
\hline NM_001560 & IL13RAI & Interleukin 13 receptor, $\alpha 1$ \\
\hline NM_000640 & IL13RA2 & Interleukin 13 receptor, $\alpha 2$ \\
\hline NM_002189 & IL15RA & Interleukin 15 receptor, $\alpha$ \\
\hline NM_000576 & $I L 1 B$ & Interleukin $1, \beta$ \\
\hline NM_004757 & SCYE1 & $\begin{array}{l}\text { Small inducible cytokine subfamily E, } \\
\text { member } 1 \text { (endothelial monocyte-activating) }\end{array}$ \\
\hline NM_000582 & $S P P 1$ & $\begin{array}{l}\text { Secreted phosphoprotein } 1 \text { (osteopontin, } \\
\text { bone sialoprotein I, early T-lymphocyte activation 1) }\end{array}$ \\
\hline NM_000594 & $T N F$ & Tumor necrosis factor (TNF superfamily, member 2) \\
\hline NM_019009 & TOLLIP & Toll interacting protein \\
\hline
\end{tabular}

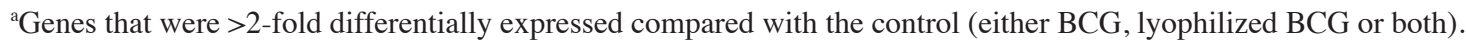

Table IV. Differentially expressed genes ${ }^{\text {a }}$ on the Human Toxicology and Drug resistance oligo array.

\begin{tabular}{|c|c|c|}
\hline Ref Seq number & Symbol & Description \\
\hline NM_005157 & $A B L 1$ & V-abl Abelson murine leukemia viral oncogene homolog 1 \\
\hline NM_005163 & $A K T 1$ & V-akt murine thymoma viral oncogene homolog 1 \\
\hline NM_138578 & $B C L 2 L 1$ & BCL2-like 1 \\
\hline NM_004327 & $B C R$ & Breakpoint cluster region \\
\hline NM_001238 & CCNE1 & Cyclin E1 \\
\hline NM_006431 & CCT2 & Chaperonin containing TCP1, subunit $2(\beta)$ \\
\hline NM_016280 & CES4 & Carboxylesterase 4-like \\
\hline NM_020985 & CHAT & Choline acetyltransferase \\
\hline NM_007194 & CHEK2 & CHK2 checkpoint homolog (S. pombe) \\
\hline NM_000754 & COMT & Catechol-O-methyltransferase \\
\hline NM_000755 & Crat & Carnitine acetyltransferase \\
\hline NM_000758 & CSF2 & Colony stimulating factor 2 (granulocyte-macrophage) \\
\hline NM_001905 & CTPS & CTP synthase \\
\hline NM_001565 & CXCL10 & Chemokine (C-X-C motif) ligand 10 \\
\hline NM_000761 & CYP1A2 & Cytochrome P450, family 1 , subfamily A, polypeptide 2 \\
\hline NM_000104 & $C Y P 1 B 1$ & Cytochrome P450, family 1 , subfamily B, polypeptide 1 \\
\hline NM_020674 & CYP20A1 & Cytochrome P450, family 20 , subfamily A, polypeptide 1 \\
\hline NM_004083 & DDIT3 & DNA-damage-inducible transcript 3 \\
\hline NM_001931 & $D L A T$ & $\begin{array}{l}\text { Dihydrolipoamide S-acetyltransferase (E2 component of } \\
\text { pyruvate dehydrogenase complex) }\end{array}$ \\
\hline NM_001539 & DNAJAI & DnaJ (Hsp40) homolog, subfamily A, member 1 \\
\hline NM_006145 & $D N A J B 1$ & DnaJ (Hsp40) homolog, subfamily B, member 1 \\
\hline NM_003315 & DNAJC7 & DnaJ (Hsp40) homolog, subfamily C, member 7 \\
\hline
\end{tabular}


Table IV. Continued.

\begin{tabular}{|c|c|c|}
\hline Ref Seq number & Symbol & Description \\
\hline NM_005225 & $E 2 F 1$ & E2F transcription factor 1 \\
\hline NM_005228 & $E G F R$ & $\begin{array}{l}\text { Epidermal growth factor receptor (erythroblastic leukemia } \\
\text { viral (v-erb-b) oncogene homolog, avian) }\end{array}$ \\
\hline NM_001964 & EGR1 & Early growth response 1 \\
\hline NM_004448 & $E R B B 2$ & $\begin{array}{l}\text { V-erb-b2 erythroblastic leukemia viral oncogene homolog } 2 \text {, } \\
\text { neuro/glioblastoma derived oncogene homolog (avian) }\end{array}$ \\
\hline NM_000122 & ERCC3 & $\begin{array}{l}\text { Excision repair cross-complementing rodent repair } \\
\text { deficiency, complementation group } 3 \\
\text { (xeroderma pigmentosum group B complementing) }\end{array}$ \\
\hline NM_005252 & FOS & V-fos FBJ murine osteosarcoma viral oncogene homolog \\
\hline NM_001924 & $G A D D 45 A$ & Growth arrest and DNA-damage-inducible, $\alpha$ \\
\hline NM_015675 & $G A D D 45 B$ & Growth arrest and DNA-damage-inducible, $\beta$ \\
\hline NM_004861 & GAL3ST1 & Galactose-3-O-sulfotransferase 1 \\
\hline NM_000847 & GSTA3 & Glutathione S-transferase A3 \\
\hline NM_000851 & GSTM5 & Glutathione S-transferase M5 \\
\hline NM_000853 & GSTT1 & Glutathione S-transferase $\theta 1$ \\
\hline NM_000854 & GSTT2 & Glutathione S-transferase $\theta 2$ \\
\hline NM_005345 & HSPAlA & Heat shock $70 \mathrm{kDa}$ protein $1 \mathrm{~A}$ \\
\hline NM_002155 & HSPA6 & Heat shock 70 kDa protein 6 (HSP70B') \\
\hline NM_001541 & HSPB2 & Heat shock $27 \mathrm{kDa}$ protein 2 \\
\hline NM_006308 & $H S P B 3$ & Heat shock $27 \mathrm{kDa}$ protein 3 \\
\hline NM_000875 & $I G F 1 R$ & Insulin-like growth factor 1 receptor \\
\hline NM_002178 & $I G F B P 6$ & Insulin-like growth factor binding protein 6 \\
\hline NM_000576 & $I L 1 B$ & Interleukin $1, \beta$ \\
\hline NM_000595 & $L T A$ & Lymphotoxin $\alpha$ (TNF superfamily, member 1$)$ \\
\hline NM_020300 & MGST1 & Microsomal glutathione S-transferase 1 \\
\hline NM_002413 & MGST2 & Microsomal glutathione S-transferase 2 \\
\hline NM_005954 & MT3 & Metallothionein 3 [growth inhibitory factor (neurotrophic)] \\
\hline NM_000015 & NAT2 & N-acetyltransferase 2 (arylamine $\mathrm{N}$-acetyltransferase) \\
\hline N M_016100 & NAT5 & N-acetyltransferase 5 (ARD1 homolog, S. cerevisiae) \\
\hline NM_003960 & NAT8 & N-acetyltransferase 8 (camello-like) \\
\hline NM_003998 & $N F K B 1$ & $\begin{array}{l}\text { Nuclear factor of kappa light polypeptide } \\
\text { gene enhancer in B-cells } 1 \text { ( } \mathrm{p} 105)\end{array}$ \\
\hline NM_002503 & $N F K B I B$ & $\begin{array}{l}\text { Nuclear factor of kappa light polypeptide gene } \\
\text { enhancer in B-cells inhibitor, beta }\end{array}$ \\
\hline NM_000625 & NOS $2 A$ & Nitric oxide synthase 2A (inducible, hepatocytes) \\
\hline NM_005122 & NR1I3 & Nuclear receptor subfamily 1 , group I, member 3 \\
\hline NM_000940 & PON3 & Paraoxonase 3 \\
\hline NM_000321 & $R B 1$ & Retinoblastoma 1 (including osteosarcoma) \\
\hline NM_030752 & $T C P 1$ & T-complex 1 \\
\hline NM_000594 & $T N F$ & Tumor necrosis factor (TNF superfamily, member 2) \\
\hline NM_003299 & TRAl & Tumor rejection antigen (gp96) 1 \\
\hline NM_003789 & $T R A D D$ & TNFRSF1A-associated via death domain \\
\hline
\end{tabular}

${ }^{\mathrm{a}}$ Genes that were $>$ 2-fold differentially expressed compared with the control (either BCG, lyophilized BCG or both).

cells $(0.43 \pm 0.09)$, and a significant decrease $(\mathrm{P}<0.05)$ in $T N F \alpha$ expression in the presence of lyophilized BCG $(0.37 \pm 0.06)$ compared with the control $(0.77 \pm 0.15)$. In the presence of orthovanadate, a tyrosine phosphatase inhibitor, the magnitude of the decrease in GSTT2 expression was reduced in cells treated with live BCG $(0.51 \pm 0.02)$ and lyophilized BCG $(0.67 \pm 0.02)$ compared with the control $(0.8 \pm 0.01)$. This indicates the modulatory function of a protein tyrosine phosphatase (PTP), either of human or mycobacterial origin. MptpA is a well-known mycobacterial PTP, and similar to Ag85B it 
Table V. Gene expression modulation by BCG in MGH and RT4 cell lines.

\begin{tabular}{|c|c|c|c|c|c|c|}
\hline \multirow[b]{2}{*}{ Gene } & \multicolumn{3}{|c|}{$\mathrm{MGH}$} & \multicolumn{3}{|c|}{ RT4 } \\
\hline & Control & Live BCG & Lyo BCG & Control & Live BCG & Lyo BCG \\
\hline GSTT2 & $1.31 \pm 0.53$ & $1.57 \pm 0.53$ & $2.50 \pm 0.88^{\mathrm{a}}$ & $0.63 \pm 0.29$ & $0.62 \pm 0.16$ & $0.56 \pm 0.33$ \\
\hline MGST1 & $0.49 \pm 0.12$ & $0.79 \pm 0.29$ & $1.10 \pm 0.43^{\mathrm{a}}$ & $0.67 \pm 0.06$ & $1.26 \pm 0.13^{\mathrm{b}}$ & $1.15 \pm 0.13^{\mathrm{b}}$ \\
\hline MGST2 & $1.27 \pm 0.27$ & $0.44 \pm 0.23^{\mathrm{b}}$ & $0.63 \pm 0.34^{b}$ & $1.36 \pm 0.23$ & $1.30 \pm 0.11$ & $1.38 \pm 0.20$ \\
\hline CSF 2 & $1.35 \pm 0.36$ & $1.05 \pm 0.12$ & $1.23 \pm 0.32$ & $0.86 \pm 0.06$ & $1.32 \pm 0.22^{\mathrm{b}}$ & $1.26 \pm 0.21^{\mathrm{b}}$ \\
\hline CXCL6 & $2.42 \pm 0.49$ & $1.14 \pm 0.13^{\mathrm{a}}$ & $1.81 \pm 1.15$ & $1.00 \pm 0.09$ & $0.75 \pm 0.04^{b}$ & $0.76 \pm 0.03^{b}$ \\
\hline CCL2O & $1.50 \pm 0.35$ & $0.82 \pm 0.05^{\mathrm{b}}$ & $0.92 \pm 0.22^{\mathrm{b}}$ & $0.95 \pm 0.10$ & $0.88 \pm 0.10$ & $1.00 \pm 0.210$ \\
\hline$I L 1 \beta$ & $1.41 \pm 0.28$ & $1.17 \pm 0.18$ & $1.23 \pm 0.22$ & $1.54 \pm 0.29$ & $1.54 \pm 0.13$ & $0.43 \pm 0.12^{\mathrm{b}}$ \\
\hline$T N F \alpha$ & $1.21 \pm 0.31$ & $1.64 \pm 0.13^{b}$ & $1.55 \pm 0.15^{\mathrm{b}}$ & ND & ND & ND \\
\hline ILI2A & $1.68 \pm 0.47$ & $0.88 \pm 0.09^{\mathrm{b}}$ & $0.99 \pm 0.24^{\mathrm{b}}$ & $1.12 \pm 0.12$ & $0.85 \pm 0.07^{\mathrm{a}}$ & $0.94 \pm 0.20$ \\
\hline ILIORB & $2.71 \pm 0.46$ & $1.15 \pm 0.12^{\mathrm{b}}$ & $1.39 \pm 0.60^{b}$ & $1.29 \pm 0.19$ & $1.17 \pm 0.24$ & $1.04 \pm 0.32$ \\
\hline TOLLIP & $1.84 \pm 0.26$ & $2.47 \pm 0.38^{\mathrm{a}}$ & $2.31 \pm 0.33$ & $0.84 \pm 0.13$ & $1.25 \pm 0.27^{\mathrm{a}}$ & $1.31 \pm 0.24^{b}$ \\
\hline CCNE1 & $2.57 \pm 0.31$ & $1.06 \pm 0.11^{\mathrm{b}}$ & $1.41 \pm 0.45^{\mathrm{b}}$ & $1.36 \pm 0.23$ & $1.09 \pm 0.34$ & $1.12 \pm 0.37$ \\
\hline
\end{tabular}

Data represented as the mean \pm standard deviation. ${ }^{\mathrm{a}} \mathrm{P}<0.05$ and ${ }^{\mathrm{b}} \mathrm{P}<0.005$ vs. respective controls using one-way analysis of variance multiple comparisons with Bonferroni correction. ND indicates the RNA was not detected. Lyo, lyophilized; BCG, Bacillus Calmette-Guérin; GSTT2, glutathione S-transferase $\theta 2$; MGST, microsomal glutathione S-transferase; CSF2, colony stimulating factor 2; CCL20, C-C motif chemokine ligand 20; IL, interleukin; TNF, tumor necrosis factor; IL10RB, interleukin 10 receptor, $\beta$; TOLLIP, Toll interacting protein; CCNE1, cyclin E1.

is a major soluble factor secreted by BCG. MptpA decreased GSTT2 expression (Fig. 3A) but exhibited no effect on $T N F \alpha$ or TOLLIP expression. Ag85B was previously demonstrated to increase cellular ROS (10). Ag85B increased TNF $\alpha$ expression, but there was no effect on TOLLIP or GSTT2 expression (Fig. 3A). This indicates that other mycobacterial proteins may serve a role in the modulation of $\mathrm{TNF} \alpha$ gene expression, as the decrease in TNF $\alpha$ was observed in the presence of a membrane insert.

GSTT2, TNF $\alpha$ and TOLLIP expression is modulated by BCG Tice ${ }^{\circledR}$ and Connaught. To determine if the gene expression changes observed were BCG-strain specific, MGH and J82 cells (which internalize BCG) (10) were exposed to BCG Tice ${ }^{\circledR}$ for $2 \mathrm{~h}$. Increased expression levels of GSTT2, TNF $\alpha$ and TOLLIP were observed in MGH cells $(\mathrm{P}<0.05$; Fig. 3B). The effects of Tice ${ }^{\circledR}$ and Connaught on MGH cells were similar (Table V; Fig. 3B). In the J82 cells, Connaught increased GSTT2 and TOLLIP expression $(\mathrm{P}<0.05)$ but had no effect on $T N F \alpha$. However, Tice ${ }^{\circledR}$ increased the expression of all 3 genes, but only $T N F \alpha$ was significantly increased. The differential response in J82 cells indicates that the responses of the two BCG strains are also dependent on host cell genetics. These results confirm that GSTT2, TNF $\alpha$ and TOLLIP are induced by the two BCG strains.

\section{Discussion}

MGH and RT4 human bladder cancer cell lines differ in the expression of several genes when unstimulated, with RT4 expressing a greater number of cytokine and chemokine genes. A limitation of the present study was that only these two cell lines were compared for the majority of the evaluations. Furthermore PCR was performed between 30-35 cycles as based on densitometry analysis of PCR products relative to cycle number; however, the PCR products were still amplifying and had not yet reached a plateau. The two cell lines responded to $\mathrm{BCG}$ by increasing the expression of $\beta$-actin and GAPDH. Therefore, neither gene is a suitable control gene for normalization of gene expression when analyzing BCG-induced early gene expression. Although GAPDH is regarded as a glycolytic protein, it regulates gene transcription, initiates apoptosis and is a major target for thiolation by ROS (17). In monocytes infected with mycobacteria, increased GAPDH expression leads to increased mycobacterial survival (18). $\beta$-actin is a cytoskeletal protein associated with cell structure, migration and the internalization of pathogens (19). BCG-induced $\beta$-actin expression may affect any of these functions.

The genes identified may be segregated by the cells lines they are expressed in as those likely to be induced by BCG internalization and soluble factors (GSTT2, MGST2, CCL20, $T N F \alpha, C C N E 1$ and $I L 10 R B)$ and those likely to be the result of BCG membrane interactions and/or soluble factors (MGST1, CXCL6, IL12A, CSF2, IL1 $\beta$, GAPDH, $\beta$-ACTIN and TOLLIP). $T N F \alpha$ was not detected in RT4 cells, and this in consistent with our previous study, which demonstrated the absence of $\mathrm{TNF} \alpha$ production prior and subsequent to BCG stimulation of RT4 cells (20).

The GSTs are a family of metabolic enzymes that conjugate reduced glutathione to electrophilic compounds such as xenobiotics, carcinogens, pesticides and other chemicals, resulting in their detoxification (21). There are 19 members. To date, GSTP and GSTM have been implicated in the development of bladder cancer, and may possibly affect the response to therapy (22). GSTT2 protects cells against the toxic products of oxygen and lipid peroxidation. The increased expression of GSTT2 may be due to the modulation of cellular lipid peroxidation by BCG (10) MGST2 and MGST1 are microsomal 
A
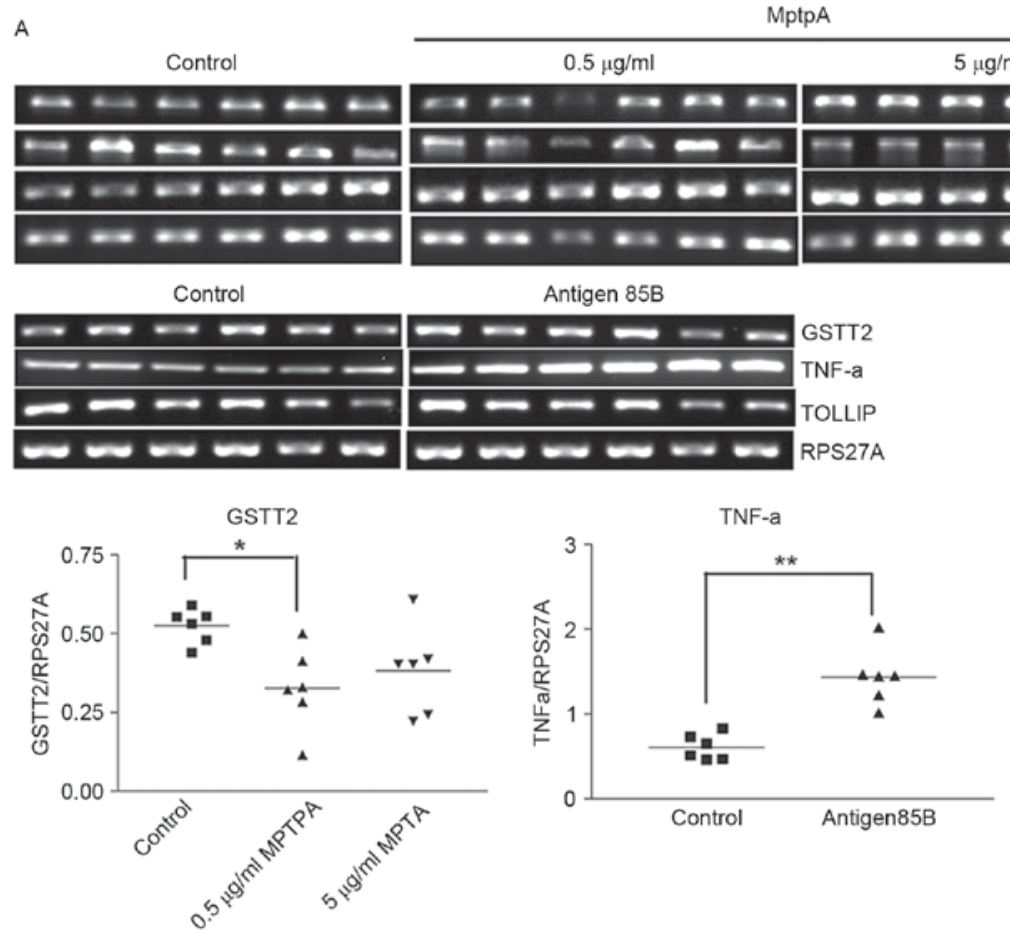

$B$

GSTT2
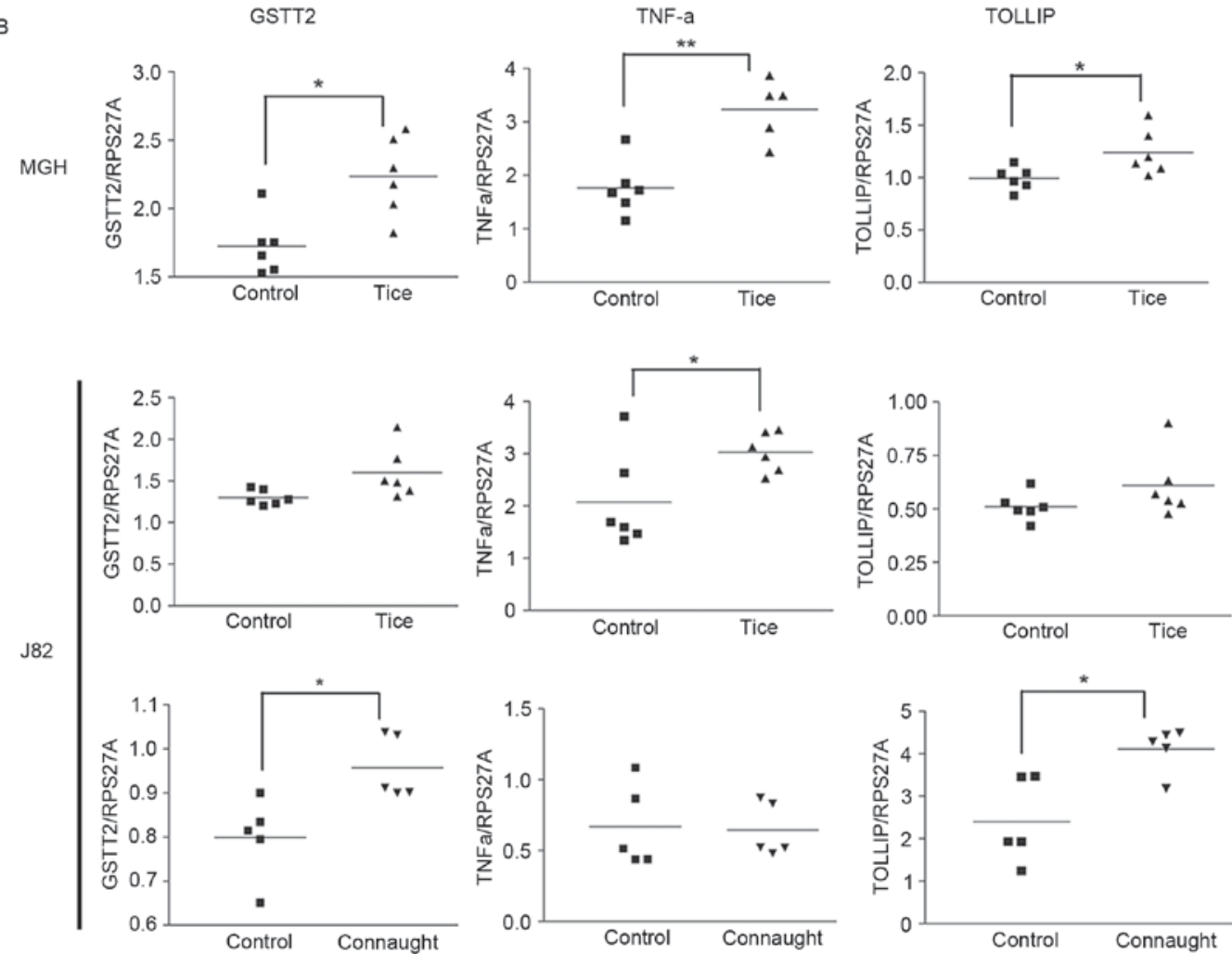

Figure 3. Modulation of gene expression by Ag85, MptpA and BCG Tice ${ }^{\circledast}$ and Connaught strains. Reverse transcription polymerase chain reaction analysis of (A) MGH cells treated with BCG secreted proteins, MptpA and Ag85B, and (B) MGH and J82 cells treated with BCG Tice ${ }^{\circledast}$ and Connaught. Gene expression was measured relative to RPS27A. ${ }^{*} \mathrm{P}<0.05,{ }^{* *} \mathrm{P}<0.005$. Comparisons between $>2$ samples were performed using one-way analysis of variance with Bonferroni correction. An independent sample t-test was used for comparing between 2 samples. GSTT2, glutathione S-transferase $\theta$ 2; TNF $\alpha$, tumor necrosis factor $\alpha$; TOLLIP, Toll interacting protein; RPS27A, ribosomal protein S27a; MptpA, Mycobacterium protein tyrosine phosphatase A; Ag85B, antigen 85B.

GSTs. MGST2 is a modulator of ROS and DNA damage, while MGST1 serves a role in eicosanoid and glutathione metabolism and has previously been revealed to block the effectiveness of doxorubicin by removing the oxidative stress induced by the drug (23). The modulation of these GSTs is consistent with the cellular ROS changes that occur following BCG internalization (6). ROS is the major means by which phagocytic cells destroy microbes (24), and the induction of the identified genes 
may serve a role in the destruction of internalized BCG. A previous study identified a single nucleotide polymorphism in GSTT2 that was correlated with recurrence following TUR in high grade bladder cancer (25), but it has not been evaluated in patients who have received BCG immunotherapy.

TOLLIP is the inhibitory protein of Toll-like receptors (TLRs). TLR activation results in homo or hetero-dimerization of these receptors, which associate with the MyD88-IRAK-4 complex (containing IRAK-1 and IRAK-2) and triggers nuclear factor (NF)- $\kappa$ B activation. TOLLIP controls Myd88-mediated activation of $\mathrm{NF}-\kappa \mathrm{B}$ by: i) Binding directly to IL-1R, TLR2 and TLR4 following TLR activation; and ii) by binding to IRAK-1, inhibiting its auto-phosphorylation. A second function of TOLLIP is in protein trafficking. TOLLP binds RAC-1 and facilitates entry of uropathogenic Escherichia coli into bladder epithelial cells (26). BCG has also been revealed to use a RAC-1-dependant pathway to enter bladder epithelial cells (5). TOLLIP expression is associated with increased interleukin-(IL)10 production and blocking of the TGF $\beta$ pathway (27). TOLLIP polymorphisms are associated with differential susceptibility to tuberculosis (28), and may perhaps also modulate the response to BCG immunotherapy.

While the cytokine and chemokine genes identified exhibit well known effects on immune activation, certain genes have also have been identified to affect phagosome function. Reduction of ILIORB may reduce IL10 signaling, which is necessary to block phagosome fusion to lysosomes (29). IL12A is also known to modulate phagosome lysosome fusion (30). $C C N E 1$, a regulator of the cell cycle, had a reduced expression and this would cause cell arrest. Therefore, the induction of these genes may modulate bacterial survival within cells. Consistent with this possibility, ILIORB and IL12A are reduced in $\mathrm{MGH}$ cells, which internalize $\mathrm{BCG}$, while there is only a reduction in $I L 12 A$ in RT4 cells that internalize BCG poorly. CSF2, CXCL6, CCL2O and TNF $\alpha$ are regulators of immune cell activation, chemotaxis and cell death. CCL20 downregulates ROS production in Mycobacterium tuberculosis (MTb)-infected monocytes (31). It remains to be determined if the other chemokines serve a role in BCG survival. Kadhim et al (32) identified the NRAMP gene as an important regulator of BCG survival, however, it is unlikely to be the only gene that performs this function, and these results may have identified several other genes that modulate BCG survival.

Rentsch et al (12) identified that immunotherapy using BCG Tice $^{\circledR}$ and Connaught produced different outcomes in patients with bladder cancer. Tice ${ }^{\circledR}$ has been suggested to be inferior to Connaught in inducing adaptive BCG-specific CD8 ${ }^{+} \mathrm{T}$ cell responses and recruiting $\mathrm{T}$ cells to the bladder (29). This may be associated with the observation that following $72 \mathrm{~h}$, Tice ${ }^{\circledR}$ exhibits a lower survival rate compared with Connaught, and a reduced ability to induce IL8 production (13). In the bladder cancer cell lines examined in the present study, there was a similar increase in GSTT2, TNF $\alpha$ and TOLLIP expression levels induced by Tice ${ }^{\circledR}$ and Connaught cells at $2 \mathrm{~h}$. Therefore, the different survival ability may be associated with bacterial genetic differences, as opposed to host factors.

Given the effects of orthovanadate and MptpA on GSTT2 expression, it is likely that a protein required for GSTT2 expression is regulated by tyrosine phosphorylation. MptpA has previously been demonstrated to modulate GSK $3 \alpha$ activity by promoting MTb survival in macrophages (33), and to modulate phagocytosis and actin polymerization (34). TNF $\alpha$ was induced in alveolar macrophages containing MTb, and it in turn increased Ag85B expression (35). In the present study Ag85B was able to induce $T N F \alpha$ expression, demonstrating an interdependent association between these 2 proteins. BCG soluble factors and whole BCG induced different effects, as observed with GSTT2 expression. Therefore, the response to $\mathrm{BCG}$ is a summation of the responses triggered by these two factors.

These results highlight the possibility that simply washing lyophilized BCG prior to therapy may modulate therapeutic outcomes by removing soluble factors. The genes identified in the present study may be good candidate biomarkers to evaluate outcomes in patients with bladder cancer receiving BCG immunotherapy.

\section{Acknowledgements}

Not applicable.

\section{Funding}

The present study was funded by the Biomedical Research Council Singapore (grant no. BMRC 04/1/21/19/311).

\section{Availability of data and materials}

The datasets used and/or analyzed during the current study are available from the corresponding author on reasonable request.

\section{Authors' contributions}

JNR performed the studies. JNR, RM and KE participated in the design of the experiments. All three authors worked on the manuscript and approved its submission.

\section{Ethics approval and consent to participate}

Not applicable.

\section{Consent for publication}

Not applicable.

\section{Competing interests}

The authors declare that they have no competing interests.

\section{References}

1. Herr HW and Morales A: History of bacillus Calmette-Guerin and bladder cancer: an immunotherapy success story. J Urol 179: 53-56, 2008.

2. Ratliff TL, Palmer JO, McGarr JA and Brown EJ: Intravesical Bacillus Calmette-Guerin therapy for murine bladder tumors: Initiation of the response by fibronectin-mediated attachment of Bacillus Calmette-Guérin. Cancer Res 47: 1762-1766, 1987.

3. Kuroda K, Brown EJ, Telle WB, Russell DG and Ratliff TL: Characterization of the internalization of bacillus Calmette-Guerin by human bladder tumor cells. J Clin Invest 91: 69-76, 1993. 
4. Chen F, Zhang G, Iwamoto $Y$ and See WA: Bacillus Calmette-Guerin initiates intracellular signaling in a transitional carcinoma cell line by cross-linking alpha 5 beta 1 integrin. J Urol 170: 605-610, 2003.

5. Redelman-Sidi G, Iyer G, Solit DB and Glickman MS: Oncogenic activation of Pak1-dependent pathway of macropinocytosis determines BCG entry into bladder cancer cells. Cancer Res 73 1156-1167, 2013

6. Pook SH, Esuvaranathan K and Mahendran R: N-acetylcysteine augments the cellular redox changes and cytotoxic activity of internalized mycobacterium bovis in human bladder cancer cells. J Urol 168: 780-785, 2002.

7. Shah G, Zhang G, Chen F, Cao Y, Kalyanaraman B and See WA iNOS expression and NO production contribute to the direct effects of BCG on urothelial carcinoma cell biology. Uro Oncol 32: 45.e1-9, 2014

8. Zhang G, Chen F, Cao Y, Amos JV, Shah G and See WA: HMGB1 release by urothelial carcinoma cells in response to Bacillus Calmette-Guérin functions as a paracrine factor to potentiate the direct cellular effects of Bacillus Calmette-Guérin. J Urol 190: 1076-1082, 2013

9. Méndez-Samperio P, Pérez A and Torres L: Role of reactive oxygen species (ROS) in Mycobacterium bovis bacillus Calmette Guérin-mediated up-regulation of the human cathelicidin LL-37 in A549 cells. Microb Pathog 47: 252-257, 2009.

10. Rahmat JN, Esuvaranathan K and Mahendran R: Bacillus Calmette-Guérin induces cellular reactive oxygen species and lipid peroxidation in cancer cells. Urology 79: 1411.e15-e20, 2012.

11. De Boer EC, Rooijakkers SJ, Schamhart DH and Kurth KH: Cytokine gene expression in a mouse model: The first instillations with viable bacillus Calmette-Guerin determine the succeeding Th1 response. J Urol 170: 2004-2008, 2003.

12. Rentsch CA, Birkhäuser FD, Biot C, Gsponer JR, Bisiaux A, Wetterauer C, Lagranderie M, Marchal G, Orgeur M, Bouchier C, et al: Bacillus Calmette-Guérin strain differences have an impact on clinical outcome in bladder cancer immunotherapy. Eur Urol 66: 677-688, 2014.

13. Secanella-Fandos S, Luquin M and Julián E: Connaught and Russian strains showed the highest direct antitumor effects of different Bacillus Calmette-Guérin substrains. J Urol 189: 711-718, 2013.

14. Pook SH, Rahmat JN, Esuvaranathan $\mathrm{K}$ and Mahendran R: Internalization of mycobacterium bovis, bacillus calmette guerin, by bladder cancer cells is cytotoxic. Oncol Rep 18: 1315-1320, 2007

15. Pastorian K, Hawel L III and Byus CV: Optimization of cDNA representational difference analysis for the identification of differentially expressed mRNAs. Anal Biochem 283: 89-98, 2000.

16. Seow SW, Rahmat JN, Bay BH, Lee YK and Mahendran R: Expression of chemokine/cytokine genes and immune cell recruitment following the instillation of mycobacterium bovis, bacillus calmette-guerin or lactobacillus rhamnosus strain GG in the healthy murine bladder. Immunology 124: 419-427, 2008.

17. Hwang NR, Yim SH, Kim YM, Jeong J, Song EJ, Lee Y, Lee JH, Choi S and Lee KJ: Oxidative modifications of glyceraldehyde-3-phosphate dehydrogenase play a key role in its multiple cellular functions. Biochem J 423: 253-264, 2009.

18. Rienksma RA, Suarez-Diez M, Mollenkopf HJ, Dolganov GM, Dorhoi A, Schoolnik GK, Martins Dos Santos VA, Kaufmann SH, Schaap PJ and Gengenbacher M: Comprehensive insights into transcriptional adaptation of intracellular mycobacteria by microbe-enriched dual RNA sequencing. BMC Genomics 16: $34,2015$.

19. Mendes-Giannini MJ, Hanna SA, da Silva JL, Andreotti PF, Vincenzi LR, Benard G, Lenzi HL and Soares CP: Invasion of epithelial mammalian cells by Paracoccidioides brasiliensis leads to cytoskeletal rearrangement and apoptosis of the host cell. Microbes Infect 6: 882-891, 2004.

20. Zhang Y, Khoo HE and Esuvaranathan K: Effects of bacillus Calmette-Guerin and interferon-alpha-2B on human bladder cancer in vitro. Int J Cancer 71: 851-857, 1997.
21. Dourado DF, Fernandes PA and Ramos MJ. Mammalian cytosolic glutathione transferases. Curr Protein Pept Sci 9: 325-337, 2008.

22. Simic T, Savic-Radojevic A, Pljesa-Ercegovac M, Matic M and Mimic-Oka J: Glutathione S-transferases in kidney and urinary bladder tumors. Nat Rev Urol 6: 281-289, 2009.

23. Johansson K, Järvliden J, Gogvadze V and Morgenstern R: Multiple roles of microsomal glutathione transferase 1 in cellular protection: A mechanistic study. Free Radic Biol Med 49: 1638-1645, 2010

24. West AP, Brodsky IE, Rahner C, Woo DK, Erdjument-Bromage H, Tempst P, Walsh MC, Choi Y, Shadel GS and Ghosh S: TLR signalling augments macrophage bactericidal activity through mitochondrial ROS. Nature 472: 476-480, 2011.

25. Ke HL, Lin J, Ye Y, Wu WJ, Lin HH, Wei H, Huang M, Chang DW, Dinney $\mathrm{CP}$ and $\mathrm{Wu} \mathrm{X}$ : Genetic variations in glutathione pathway genes predict cancer recurrence in patients treated with transurethral resection and bacillus Calmette-Guerin instillation for non-muscle invasive bladder cancer. Ann Surg Oncol 22: 4104-4110, 2015

26. Visvikis O, Boyer L, Torrino S, Doye A, Lemonnier M, Lorès P, Rolando M, Flatau G, Mettouchi A, Bouvard D, et al: Escherichia coli producing CNF1 toxin hijacks Tollip to trigger Rac1-dependent cell invasion. Traffic 12: 579-590, 2011.

27. Zhu L, Wang L, Luo X, Zhang Y, Ding Q, Jiang X, Wang X, Pan Y and Chen Y: Tollip, an intracellular trafficking protein, is a novel modulator of the transforming growth factor- $\beta$ signaling pathway. J Biol Chem 287: 39653-39663, 2012.

28. Shah JA, Vary JC, Chau TT, Bang ND, Yen NT, Farrar JJ, Dunstan SJ and Hawn TR: Human TOLLIP regulates TLR2 and TLR4 signaling and its polymorphisms are associated with susceptibility to tuberculosis. J Immunol 189: 1737-1746, 2012.

29. Montaner LJ, da Silva RP, Sun J, Sutterwala S, Hollinshead M, Vaux D and Gordon S: Type 1 and type 2 cytokine regulation of macrophage endocytosis: Differential activation by IL-4/IL-13 as opposed to IFN-gamma or IL-10. J Immunol 162: 4606-4613, 1999.

30. Jung JY and Robinson CM: IL-12 and IL-27 regulate the phagolysosomal pathway in mycobacteria-infected human macrophages. Cell Commun Signal 12: 16, 2014.

31. Rivero-Lezcano OM, González-Cortés C, Reyes-Ruvalcaba D and Diez-Tascón C: CCL20 is overexpressed in Mycobacterium tuberculosis-infected monocytes and inhibits the production of reactive oxygen species (ROS). Clin Exp Immunol 162: 289-297, 2010.

32. Kadhim SA, Chin JL, Batislam E, Karlik SJ, Garcia B and Skamene E: Genetically regulated response to intravesical bacillus Calmette Guerin immunotherapy of orthotopic murine bladder tumor. J Urol 158: 646-652, 1997.

33. Poirier V, Bach H and Av-Gay Y: Mycobacterium tuberculosis promotes anti-apoptotic activity of the macrophage by PtpA protein-dependent dephosphorylation of host GSK $3 \alpha$. J Biol Chem 289: 29376-29385, 2014.

34. Castandet J, Prost JF, Peyron P, Astarie-Dequeker C, Anes E, Cozzone AJ, Griffiths G and Maridonneau-Parini I: Tyrosine phosphatase MptpA of Mycobacterium tuberculosis inhibits phagocytosis and increases actin polymerization in macrophages. Res Microbiol 156: 1005-1013, 2005.

35. Islam N, Kanost AR, Teixeira L, Johnson J, Hejal R, Aung H, Wilkinson RJ, Hirsch CS and Toossi Z: Role of cellular activation and tumor necrosis factor-alpha in the early expression of Mycobacterium tuberculosis $85 \mathrm{~B}$ mRNA in human alveolar macrophages. J Infect Dis 190: 341-351, 2004.

This work is licensed under a Creative Commons Attribution-NonCommercial-NoDerivatives 4.0 International (CC BY-NC-ND 4.0) License. 